\title{
THE ACCIDENTAL TRAVELLER: PRISCILA UPPAL'S SEARCH FOR HER FUGITIVE BRAZILIAN MOTHER
}

\author{
Albert Braz \\ University of Alberta Edmonton
}

\begin{abstract}
Travel writing is often perceived as being inevitably informed by a colonial ethos, particularly since the authors of travelogues by necessity must discern differences between their homelands and the societies they describe. However, Priscila Uppal's 2013 memoir Projection: Encounters with My Runaway Mother illustrates that accounts of journeys to other countries are not always primarily motivated by global politics but rather by family dynamics. After all, sometimes one sees a country in a given manner simply because it happens to be the birthplace of people one has come to resent, such as the mother who abandoned you as a child.
\end{abstract}

Keywords: Canada; Brazil; Travel; Transcontinental crossings.

Somos todos Americanos.

We are all Americans.

Guillermo Verdecchia

Against all political correctness,

I must say it,

I must admit:

I'm afraid of Brazilians.

Priscila Uppal

People usually travel to foreign destinations because they are intrigued by them, be it their rich historical or cultural past, their lush landscape, or some other exotic element. This, though, was not what precipitated Priscila Uppal's 2003 trip to Brazil, a country that purportedly held no appeal whatsoever for her. Rather, the only reason the Canadian poet and novelist journeyed to South America was to meet her fugitive Brazilian mother, the mother who abandoned her and her brother as children and whom she had not seen for nearly twenty years. Uppal's impressions of Brazil are thus inevitably influenced by the fact it is the homeland of her truant maternal progenitor. Yet what makes her account of her transcontinental crossing in
Projection: Encounters with My Runaway Mother so compelling is that she not only discovers she shares many personality traits with her mother and her family but also that, at times, she seems more at home in foreign Brazil than in her native land. That is, as I will attempt to show in my essay, Uppal's experiences in Brazil are profoundly complicated by her awareness that this alien and alienating country is also her ancestral homeland, problematizing the distinction between home and away.

The discourse on travel writing continues to be informed by the idea that this "quasi-fictional genre" necessarily embodies a "colonial ethos" (Lisle 1, 20; see also C. Kaplan 2). As Debbie Lisle asserts in The Global Politics of Contemporary Travel Writing, "the genre has always been implicated in the political logic of Empire" (265). Or as Mary Louise Pratt declares in her influential study Imperial Eyes: Travel Writing and Transculturation, along with "enlightenment natural history", travel writing helped "to produce a Eurocentered form of global or [...] 'planetary' consciousness," which should compel politically-aware contemporary scholars to

\footnotetext{
* Albert Braz is an Associate Professor of English and Comparative Literature at the University of Alberta. He specializes in Canadian literature in both its national and inter-American contexts, being especially interested in literary and cultural representations of the relations between Natives and Newcomers. He is the author of The False Traitor: Louis Riel in Canadian Culture (2003) and of Grey Owl: The Writer and the Myths (forthcoming) and the co-editor of an issue of the Canadian Review of Comparative Literature on Comparative Canadian Literature (2009) and of an issue of CLCWeb: Comparative Literature and Culture on Indigenous Literatures (2011).E-mail: abraz@ualberta.ca
} 
produce works designed "to decolonize knowledge" (5, 2). There is no question that there are limitations to the inclusiveness of even the most cosmopolitan of travel writing. After all, the authors of travelogues "still need other places and people to visit and write about-which means that travel writers must always engage in the production of difference" (Lisle 24). That being said, the notion that the logic of empire informs all travel writing seems dubious in an account of a journey between Canada and Brazil, two formerly colonized countries that are so "routinely ignored" in discussions of the continent in which they are situated that, together, they have been branded "Outer America" (Braz, "Outer America” 120). Also, while Uppal structures her memoir around two women who identify openly with the northern and southern parts of the continent, she inverts the typical inter-American racial script, since the northern woman (Uppal) is of mixed race and the southern one (her mother) is white. Most significant perhaps, Uppal's text is deeply affected by the author's sense of maternal rejection, of abandonment. So in a way, Projection is less about global politics than about family dynamics in general and parental responsibility in particular, a Canadian writer's jeremiad about being forsaken by her Brazilian mother.

Priscila Uppal, who is currently a professor of Humanities and English at Toronto's York University, is an acclaimed and prolific poet and novelist. Since 1998, she has published nine collections of poetry, two novels, and a scholarly study of Canadian elegies. Uppal has also produced a play about her trip to Brazil. Titled 6 Essential Questions, it premiered in Toronto in early 2014 and supposedly freed her from the factual constraints of her memoir, allowing her to be "as surreal and absurd and poetic as I wanted to be" (Uppal, "Q\&A" n. pag.). In addition, she has edited several anthologies of poems and essays and was the 2010 Vancouver Olympics poet-in-residence for Canadian athletes (priscilauppal. ca). Uppal was born in Ottawa in 1974 to two recent arrivals in Canada, an immigrant from India named Avtar Uppal and Theresa Catharina de Góes Campos, the daughter of the military attaché to the Brazilian Embassy. Her father, as Uppal writes in her memoir, was "an up-and-comer, a tall-dark-and-handsome intelligent civil servant, a junior project manager for the Canadian International Development Agency (CIDA), responsible for overseeing the building of infrastructure projects on eight Caribbean commonwealth islands" (Projection 3). The young family's prospects thus looked auspicious. But early in 1977, when the future author was two-years-old and her brother Jit was three, her father "swallowed contaminated water during a sailboat accident in Antigua. The water mercilessly attacked his immune system in the form of transverse myelitis (a neurological disorder caused by an inflammatory process of the spinal cord) [and] within forty-eight hours" he was rendered "a quadriplegic" (3-4). "Overnight," explains Uppal, her mother "was cruelly cast in a new role: no longer the beaming wife in a thesky's-the-limit immigrant mixed-race love story, but the suffering heroine of a tragic family melodrama," in which she was "required to attend to the relentless needs of an invalid day and night" (4). Campos seems to have been unable or unwilling to accept her new reality and, six years later, she abandoned her family. She drained "all the money from the bank accounts," including her children's "small savings," and "purchased three plane tickets for Brazil" (5). She tried to take Priscila and Jit with her but, when they resisted, she disappeared from their lives. Uppal, like her brother and their father, would have no contact with her for almost two decades; both her father and brother still refuse to have anything to do with her, with Jit usually "telling people she's dead" (171; see also Uppal, "Poem” 162).

Uppal has described "the swift flight of my mother from our home when I was eight" as one of "the defining moments of my life-personally and artistically" ("My Uncontainable Mother" 42). She also notes that her work reveals an obsessive fascination with mothersparticularly missing mothers-and concedes that, whether she likes to admit it or not, she has been "diligently searching her [mother] for years, trying to contain in writing the complex emotions associated with her abandonment" (42). As she addresses the subject in her poem "Mother's Death," she has been waiting for "your ghost to surface/ from the basement" (Confessions 28). In fact, it was because of her writing that Uppal rediscovered her mother. While searching for 
reviews of her first novel on the Internet in September 2002, she accidentally came across a link that included both her name and her brother's. To her shock, when she extended her investigation, she encountered "the personal website of my runaway mother, a person I hadn't seen or heard from and whose name I hadn't spoken aloud in twenty years" (Projection 12), who was now a journalist, writer, and university lecturer in São Paulo. To dispel any doubt regarding the identity of this virtual person, under "the banner heading Sobre minha família e meus amigos," Uppal found "my childhood self, and my brother-two and three years old. She'd posted a photograph of us in clothes I recognized as ones she had made [...], nestled in front of my mother with her signature 70s-style wide orange hairband setting her black shoulder-length hair in place" (12-13). The only member of the family missing from the picture is her father, who similarly has developed the habit of excising his estranged spouse from family portraits.

Since Campos's website was all in Portuguese, a language Uppal does not speak, she was forced to turn to the automatic translator, "a function I'd never used before" (14). Then upon learning that her mother had cancer, she knew instantaneously what the illness "meant to me. It hit me as hard as the fateful click of that [computer] mouse. 'I'm being told to go. To go see her. Meet her. If I wait any longer, I might not get another chance"' (14). In consultation with her partner, Chris Doda, she decided to telephone Campos, who responded by inviting her to visit her in São Paulo. So in early April 2003, after missing a flight because of complications over an unexpected tourist visa, Uppal embarked alone on her "prodigal journey" to Brazil to reconnect with her mother (19). Alas, the meeting did not go well, as she details in her memoir.

Projection: Encounters with My Runaway Mother is not Uppal's first engagement with her mother, and her elusive land. For instance, in her 2010 collection Traumatology, Uppal includes a poem titled "My Mother Is One Crazy Bitch," which begins:

How do you write that on a postcard?

How will I tell my brother, that yes, yes, I found our mother after twenty years and she's about as lovely as an electrical storm when you're naked and tied to the highest tree in the country. (Traumatology 47)

The poem had actually appeared two years earlier, 2008, in a sequence called "Brazil, Under These Circumstances" (86), in which Uppal relates how difficult it is to trust her mother, given that for the last two decades "she has been a terrorist/ silently bombing our family album" ("Brazil" 82). Part of the reason that the ten days she spends with her mother in São Paulo are so "turbulent" is that Uppal arrives in Brazil "without language and with little knowledge of Brazilian culture." No less important, as she stresses, "place is affected by our imaginative perceptions of our families." Therefore, her "Brazil, like a runaway mother, constantly changes, from exotic jungle to criminal haven to government town to a treasure trove of garbage" ("Brazil" 79), underscoring the strangeness of both the cultural and human geography she encounters.

The extent to which Uppal is unable to separate her perception of Brazil from that of her mother is never more evident than in her 2006 poem "I'm Afraid of Brazilians or Visiting the Ancestral Homeland Is Not the Great Ethnic Experience Promised by Other Memoirs." The work from which I borrow the second epigraph to this essay, "I'm Afraid of Brazilians" anticipates her memoir in conveying the author's profound anxieties about her journey south:

Against all political correctness,

I must say it,

I must admit:

I'm afraid of Brazilians.

I don't like them.

I don't like this country.

I don't like this language.

I don't even like this currency.

I'm afraid of Brazilians.

I am visiting Brazil

(my mother's country)

and I'm afraid, truly afraid,

of everything Brazilian I meet. (Ontological Necessities 58) 
Uppal, who wrote the poem after meeting her mother ("Fear" n. pag.), has characterized it as "a hyperbolic salvo of paranoid proportions countering myths of prodigal returns. My speaker did not discover her 'true self' or 'her people', only infinite fears" ("My Uncontainable Mother" 42). Yet at least one commentator, the Indian poet and journalist Tishani Doshi, considers "I'm Afraid of Brazilians" her "personal favourite" among Uppal's poems (para. 4). Whatever else it may do, it certainly captures the state of "being afraid" (Uppal, Ontological Necessities 59) of the new, the unfamiliar, even if that happens to be one's own mother and her country.

Considering that Campos is a film critic, Uppal attempts to convey their relationship by structuring each chapter of Projection around one of her mother's favourite films, from Blade Runner and Maid in Manhattan, through Mommie Dearest, to Deus é brasileiro (God Is Brazilian) and Bye bye Brasil. Yet even the make-believe world of movies cannot camouflage the lack of connection between mother and daughter, a rift that underscores the fact both women instinctively accept that, by travelling to Brazil, Uppal has entered physically unsafe territory. Even before leaving Toronto, Uppal is concerned about how she is going to "navigate a foreign culture and language in one of the most dangerous countries in the world" (23), as befits " $a$ machismo culture" (20). As she observes toward the end of her memoir, "the elderly are revered in Brazil" because "if you can live this long in such a dangerous country, you must have learned a thing or two" (202). If anything, Brazil's pervasive urban violence is accentuated by her mother. When Uppal first arrives in São Paulo, Campos tries to help her adjust to the country (and to her) by having the two stay at the "Caesar Park, a luxury hotel with a glass elevator and towering palm trees" near Guarulhos International Airport (31). They go to the nearby mall to get the lay of the land, and her mother immediately warns Uppal: "Be careful with your purse. Even in the shopping mall. I've been mugged four times" (36). Soon they move to her mother's rented flat in the centre of the city, "a suite-style hotel geared toward long-term stays for families and business travellers" (52), which among other amenities has "a 'piscina' on the rooftop, labelled 'indoor' for some reason" that she cannot figure out (60). Uppal decides to take a stroll in the neighbourhood, to see what kinds of stores they have there, and she discovers that she is being followed by a young desk clerk with the unlikely name of Aleshandro, who informs her that she "must not go out." As Aleshandro explains to a bewildered Uppal, "Your mother does not wish for you to go out on your own," because "São Paulo dangerous. Not Canada. You must not get hurt" (62). Or as he elaborates, "You English. You kidnapping target" (63).

The dangers of São Paulo are also stressed in an exchange between Uppal's mother and her regular taxi driver, Soares, which constitutes what Uppal terms an "ironic tourism pamphlet" (67). The dialogue is worth reproducing in full, since she hears it soon after landing in Brazil and it serves as part of her introduction to the country:

\begin{abstract}
Ninety-one people die violently in Brazil every seven hours. Ninety-one Americans have died in the entire Iraqi war thus far. It is safer to be an American soldier on the front lines of war than a Brazilian..... See those children there, looking innocent, they are part of a gang, they will take not only your purse, but your shoes and socks and pants and anything else they can. . ... São Paulo is no place to work. Brasilia is dangerous too, because people know many people living there are middle class or higher. There is money to steal. American money is very popular to steal. Everyone will assume you are American. No one knows what a Canadian looks like. They will take the chance that they are robbing an American. (67; ellipses in text).
\end{abstract}

Not surprisingly, Uppal will be restricted to seeing only a limited part of Brazil, since the locals, notably her own mother, do not believe that she can safely navigate the urban landscape at will. To further complicate matters, her body itself does not adjust well to the new environment. She starts getting stomach cramps almost as soon as she arrives, which become so severe that they not only disrupt her sleep but worry everyone around her (97).

Moreover, Uppal cannot compensate for her lack of access to the outdoors in São Paulo by bonding indoors 
with her newly-discovered mother, since the two can barely tolerate each other. About half way through the memoir, during one of their increasingly acrimonious verbal spats, Uppal tells her mother that she envisaged her visit to Brazil as "a gift, an opportunity .... I came here to get to know who you are and for you to get to know who I am" (143). Her mother is not quite persuaded, saying that her friends have told her that "you came here for vengeance" (141). At any rate, there are indications in the text that Uppal is less determined to get to know her mother, including discerning why she abandoned her family, than she is in finally having a mother who loves her unconditionally and is captivated by every detail of her life merely because she is her offspring.

Throughout the memoir, Uppal provides a litany of complaints about her mother's purported lack of interest in her. Even though she is in her late twenties when she reconnects with her mother, she often sounds like a wounded little girl searching desperately for the maternal love of which she was deprived as a child and who is bitterly disappointed to realize that she still has not found it, and likely never will. As Uppal bemoans her mother's apparent lack of maternal love: "It is at breakfast when I realize that aside from questions about my flight, my mother has not asked me a single question about my life since I've landed" (50). Or later, "Why has she still not asked me anything about my own life? Where I've travelled. What my $\mathrm{PhD}$ is about. If I've been diagnosed with an illness. If I've ever been in love" (84). In her analysis of one of her mother's favourite films, Luc Besson's The Big Blue, Uppal writes that " $[\mathrm{t}]$ he void created by a missing mother's love is deeper than the earth, deeper than any mortal lover can fill" (55). However, her mother's behaviour prompts her to reassess her statement. "This woman has no interest in any story other than the one she's constructed" (86), she surmises, leading her to deduce that she probably made a mistake travelling to South America.

Part of Uppal's resentment toward her mother reflects her child-like dependence on her while in Brazil. Because of her lack of knowledge of Portuguese and her unfamiliarity with Brazilian culture, Uppal is utterly reliant on her mother. In the process, she also becomes infantilized, "crippled" by her "lack of . . . language"
(Page, Brazilian Journal 26). As an earlier Canadian visitor to Brazil, the poet P.K. Page, noted about her sojourn in the country in the 1950s, "Not only do I talk a kind of baby talk, with an appalling accent, but the things I actually say are often quite different from what I meant to say" (Brazilian Journal 26-27). In a short story, Page perceptively observes that the lack of fluency in a language often results in a "reversion to infancy" ("Fever" 20; see also Braz, "Missing Continent" 48), a reality that Uppal does not fully appear to recognize. Campos not only pays for all of Uppal's expenses, except airfare (83), but she becomes her daughter's necessary guide. In fact, she is a sort of a Vergil to her Dante, guiding her foreign daughter through the São Paulo and Brazilian labyrinths. Yet instead of admiring her guide, Uppal comes to hate and fear her (86).

So volatile is the relationship between mother and daughter that, before long, Uppal is pondering cutting her trip short and returning to Toronto. As she asks herself at one point, "What the hell am I doing here? I've never had any urge to visit Brazil. I've dreamt of Paris, London, Berlin, Stockholm, Melbourne, St. Petersburg, Vienna, Oslo. Never São Paulo. Brasilia. Rio" (141). Her antipathy toward Brazil seems to have a strong personal dimension. To begin with, Uppal associates not only Brazil but the tropics in general with catastrophe, as both she and her brother "for a long time connected tropical landscapes with my father's paralysis" (91). In addition, she is profoundly troubled by her resemblance to her mother-from the "prolificness" she believes she gets from her (34), through the fact they are "both workaholics and resent the physiological demands of sleep" and are "charming to strangers" (56), to their finding a mutual outlet for their dissatisfaction in writing (72). She particularly dreads that her affinities with her mother may not only reflect poorly on her but also constitute a betrayal of her father. "One of my biggest fears as I grew older," she confides, "was that I would look too much like my mother and my father would hate me by instinct" (66). Significantly, she adds that when she was offered her professorship, her father "sighed with relief, wrongly concluding: 'Now you can finally stop writing those books.' I imagine he was wary of me following in any way in my mother's footsteps, 
connecting her penchant for the arts with her declining mental state" (91). Most critical perhaps, Uppal comes to perceive her mother's forsaking of her family as being linked to her nationality. After all, is she not "that woman who left her husband and two children for Brazil?" (86). Or to put it differently, for Uppal, Brazil itself may be partly responsible for depriving her and Jit of their mother when they were children.

Although Uppal comes to loathe her mother, she decides not to end her trip prematurely because, like so many other travellers, she is hoping to write about her experiences. Travel writing theoreticians such as Michel Butor have long argued that there is a direct link between travel and writing. As Butor states, "I have always felt the intense bond that exists between my travels and my writing; I travel in order to write- not only to find subject matter, topics or events [...]-but because to travel, at least in a certain manner, is to write (first of all because to travel is to read), and to write is to travel" (2). This would also seem to be true of Uppal, who candidly "admit[s] that one of the things keeping me by my mother's side at this point is the fact that I'd like to write about her" (171). She evidently had been hoping to write about her mother for most of her adult life. Uppal relates that "since I was eighteen and had started writing seriously at university, I entertained the idea of embarking on a trip to find my runaway mother, and to write a book about the journey even if I didn't find her," which "for some reason I actually believed I wouldn't" (9). Besides, she comes to suspect that her mother's ostensible lack of affection toward her may reflect the fact "she knows I'm writing about her." Uppal observes that her "notebook is [...] ubiquitous," and that she has "even started to take notes while [her mother] is talking because she doesn't register my actions" (129). To further problematize the situation, her mother too may be planning to write about Uppal's visit to Brazil. When Uppal charges that, after all those years apart, Campos not only knows nothing about her but has no interest in learning about her, her mother responds: "No. I know you very well. In the last six days I know enough to write a book about you!" (140). Perhaps Uppal is not the only one who is planning to write about their "bizarre relationship" (Uppal, "In Conversation" 20).
In any case, the chemistry between Uppal and her mother never improves during the trip. If anything, things deteriorate even more after they travel to Brasília during the Easter weekend to meet the rest of the family. Uppal becomes especially close to her grandmother, a "light-skinned white-haired woman in her late seventies with sparkling blue eyes" (175). She confesses that she is "fond" of the matriarch, who is "elegant and exudes grace and power" (195), even pondering if what she feels for her is "love" (205). The Góes Camposes are expatriates from Rio de Janeiro who relocated to Brasília in the mid-1960s, after Brazil moved its capital from the coast to the interior of the country, and Uppal is clearly proud to belong to such a distinguished clan. Early on she finds out that her grandfather was "a pilot in the Brazilian Air Force" before becoming a diplomat and that one of her uncles is the "head of the Air Force" (33). As her mother informs her, with undisguised pleasure, "Airplanes are part of our family. My father was a pilot, and your Uncle Wilhelm and his children are all pilots. Very good jobs. Uncle Wilhelm is head of the Air Force and has met the pope" (101). Uppal, however, is most touched when she learns that her great-grandfather was "a composer and a professor at the National Conservatory in Rio" and has a "street [...] named after him in Ipanema" (205), that a great-uncle "wrote poetry and a very famous grammar book" and a cousin was "also a poet," and that they too have streets named after them in Rio (206). So pleased is she to discover that "there were so many artists, and poets no less, in the family" that she declares this is one "family tradition I don't mind embracing." Indeed, she then sets "a new impossible goal for myself: I must have a street named after me," dreaming that the Ottawa street where she grew up, Erinbrook Crescent, "will one day be renamed Priscila Uppal Crescent” (206).

Perhaps not accidentally, as Uppal starts to identify with her extended Brazilian family, she drifts further away from her mother. While in Brasília, Uppal and Campos have another clash during which Uppal says that she at last comes to "understand that maybe $I$ am someone she'd like to kill" and accuses her mother of living in "a fantasy world" (180). To this Campos retorts, "I did not go to Canada to bother you. You forget, you are in MY place and you will do as I say. This is MY 
family, Priscila, remember that. Not yours" (180). Yet, even though Uppal concludes that she and her mother are "strangers tied by blood and crushed dreams" and that "I don't need a mother. And I no longer desire one" (257), it is clear that she has gained entrance into the maternal side of her family. Upon returning to Canada, Uppal asserts that she does not think she will "be visiting Brazil again anytime soon" (259). But she then proceeds to disclose that in 2005 , two years after her original trip, she went back to Brazil. Travelling with her partner this time, she went to Brasília to see her grandmother and her enigmatic uncle Fernando, a professor of mathematics and economics and an expert in waste management who "love[s] garbage, more than people" (219; see also 263). From there, Uppal and her partner went to Rio to meet some more relatives and to explore the family's ancestral hometown. It seems fair to deduce that, regardless of her feelings about her "lunatic mother" (206), her prodigal journey to South America is not quite over. Perhaps the "stocky and dour woman" who attends Uppal at the "cold, unfriendly" Brazilian consulate in Toronto is correct when she informs the Canadian traveller, "If your mother is Brazilian, then you're Brazilian"' (23). Or at least, if your grandmother and her family are Brazilian, then Brazil is not quite an alien country.

There are several fascinating aspects about Uppal's account of her discovery of Brazil in Projection. Most of these of course focus on her explosive reunion with her mother, with whom she has "not been in touch" since her initial visit (Sunshine n. pag.). Reviewers of the memoir, who so far are largely Canadian, tend to accept Uppal's version of her relationship with her mother. One critic describes Campos as "a smiling monster in bright orange accessories" (Barmak R13); another as "a caricature of a person who has abandoned reality and lives in a land of make believe" (Kienlen n. pag); and still another as "selfish, unreliable and maddening" (Yanofsky n. pag.). Or as Elizabeth Saunders, the actor who plays Campos in Uppal's play about her Brazilian odyssey, characterizes her, she is "a hysterical narcissist who's larger than life" (qtd. in J. Kaplan n. pag.). However, even those critics who praise the memoir often note that it makes little effort to represent the perspective of the author's mother.
Admittedly, it is not easy to sympathize with Campos, both because of her apparent self-centredness and her lack of self-knowledge. Despite the fact she abandoned her children and quadriplegic husband and moved to another country, she casually tells the daughter she has just seen for the first time in two decades, "Ethics is everything" (41). The most conspicuous example of her lack of introspection is arguably a poem that Campos posts on her personal website. Titled "A Mãe: Sua presença na vida dos filhos," it was written in Recife when she was fourteen-years-old:

Aquele que tem, na vida, a presença de uma querida Mãe para guiá-lo

pelas sombras do destino, não pode ser infeliz.

As plantinhas, quando privadas da luz do sol, somente com muito cuidado conseguem viver. As crianças, na sua casa, têm na Mãe uma estrela que as aquece com o calor do seu precioso amor, iluminando-as com a sabedoria dos seus conselhos.

A Mãe é o tesouro dos filhos porque o seu carinho e a sua dedicação são

imensos; porque ela, na alegria, é também feliz conosco; na tristeza, a sua

mão pousa sobre nossa cabeça, ternamente, como para aliviar os nossos

sofrimentos e as nossas múltiplas preocupações.

E assim, em todas as épocas, as Mães, jardineiras competentes, vão

cuidando dos botões que desabrocharão em lindas rosas, apalpando e

revolvendo a terra, regando as plantinhas, retirando as ervas daninhas,

para que os botões possam florescer em toda a plenitude, realizando, então, o fim para que foram criados.

Given Campos's treatment of her children, " $A$ Mãe" could easily be seen as an indictment of her own behaviour. But counterintuitively, Campos appears to believe that she is a good mother, if not a model one. As she writes in "Messages to My Darling Son Amerjit," which she posted on the Internet in her attempt to have her children "get in touch with" with her, "I love you very much and I miss you a lot" and "I hope you do 
remember the years we were together and the fact that I did all I could, as a mother, to keep us together." From her perspective, she is not a truant parent but a loving one, and possibly a victim.

Still, one must not forget that the reader's view of Campos, like that of Brazil, is mediated by Uppal, who is a "storyteller" (Bailie 23). The novelist Martha Bailie describes Projection as an "intimate, sad, probing and self-aware, often very funny logbook of a harrowing encounter." Yet she then remarks that Uppal goes to Brazil "as a vulnerable daughter" as well as "a highly skilled novelist armed with the intention of writing a book" (23). The literary critic and memoirist Joel Yanofsky is even more critical. He praises Uppal's book as "a raw, passionate memoir, a fierce exercise in family exorcism" and states that the author's "mother is deserving of much of the contempt heaped upon her." At the same time, he reveals that he finds Uppal's approach so monologic that, as he read the text, he "could feel my allegiances shifting, against my will and better judgment, from daughter to mother" (n. pag.).

Yanofsky is particularly adept at identifying the parallels between the two women when it comes to family obligations. In a few laconic passages in her memoir, Uppal acknowledges that she too left home. In one of their arguments, she reminds Campos that one of the "consequences" of her abandoning the family was that "I had to take care of my father and my brother: shopping, cleaning, cooking, medical procedures. I had a Visa card with my name on it at ten years old" (147). But in the very next sentence, she adds that "I was so old and worn out by the time I was fifteen that I left home and have been self-supporting ever since. It was easier for me to work full-time and go to school fulltime and earn A-pluses across the board than it was for me to keep the household functioning" (147). Earlier in the text, she refers to "a particularly angst-ridden time after leaving home at age fifteen for rented rooms" (57). She further asserts that "there are good reasons I left home at fifteen" and implies that they have something to do with her father's parenting (124); incidentally, she notes in passing that her father "still lives at home. With my brother" (220) and that he "doesn't want gifts [from Brazil]. What he wants is for me to visit him more often. What he wants is for me to forgive him for those awful teenage years that drove me out of our house" (240). Yanofsky does not question that Uppal had valid reasons for leaving home. But he does point out that there is "no sense in Uppal's telling of the story of how this act must have resonated for her father and brother or even her. I could never shake the feeling that on some level this must have seemed to everyone involved like she was following in her mother's footsteps" (n. pag.). In other words, part of Uppal's animus toward her mother may be explained by the fact she fears she resembles her, that she is replicating her mother's actions.

Another aspect of Projection of which Yanofsky is critical is Uppal's self-promotion. He observes that both the memoir and the author are "remarkably free of self-pity." Yet he contends that although Uppal is "justifiably proud of her ability to care for her disabled father while still getting straight A's," she is "also not averse to boasting about her accomplishments as a poet, novelist, tenured professor," and so on (n. pag.). There is a definitely a streak of the Nietzschean Übermensch in Uppal, often mixed with a considerable element of disingenuity. She frequently emphasizes her intellectual and psychological fortitude. For example, she writes that the reason she has no qualms about confessing that she avoids calling "my mother 'mother" and that "I just don't feel like her daughter" is that she does not have "the Canadian passive-aggressive gene" (191). She also relates that her high school principal allowed her to sign her own sick notes because "I had a near 100 percent average" (57). She elaborates that the teachers "said nothing" about her absences for she "unnerved them: a straight A+ student and jock who wrote dark poetry and stories about suicide for the school newspaper and worked full-time as a pharmaceutical assistant in addition to her classes. I was like a science experiment set to explode. The teachers stood back to avoid the fallout, but took interest in observing the anomalous results" (57-58). Again, she is exceptional, which is why she is granted special status.

Interestingly, Uppal finds a parallel between her behaviour and that of her mother, who supposedly also has the ability to smile in the face of adversity. As she reflects: 
She laughs a lot. Like I do. Our personalities are more similar than I'd like to admit. I, too, have found putting up a good front, keeping one's head up and smiling and laughing no matter what the circumstances, impresses people and makes them want to be around you, even help you. As a child, this is how I survived, forever pleasing those in authority-teachers, coaches, friends' parents-by being the child who surpassed all others in test scores, who accumulated the most assists on a basketball court, who would enthusiastically offer to wash the dishes after a home-cooked meal [...]. My friends' parents welcomed me as a positive influence as if math and science and geography rubbed offlike chalk. Look at what she's been able to accomplish, and under such circumstances! "Such circumstances" being, of course, a sick father and a non-existent mother; and, later on, a fifteen-year-old living successfully on her own, going to school full-time and working full-time at a drugstore, paying her bills and gunning for university scholarships. (71-72)

Uppal highlights that, from a young age, "I learned to take care of my illnesses-from colds to flus to sinus infections-on my own" (57). Perhaps even more telling, she boasts that since she left home as a teenager and realized she was "alone in the universe, without a proper protector, without someone to fight for and care for me," she has adhered to "a revelation" she had one "singular morning: breakdowns are a luxury I cannot afford" (57), implying that mental illnesses are a choice and only the weak succumb to them.

In addition to Uppal's exploration of her relationship with her mother, which sometimes reveals more about the author than about Campos, there are several fascinating aspects about her account of her encounter with Brazil. One is quite typical, which as I noted earlier is her focus on urban violence, her overwhelming sense that she has entered an unsafe space. Uppal's almost debilitating anxieties about the dangers lurking in her mother's homeland appear to be confirmed once she returns to Canada. She suspects that the physical ailments she experienced throughout her Brazilian trip are probably related to her early awareness that her mother "rejected" her (259). However, upon consulting her family physician, she learns that her "stomach problems are not stress-related [...], but the result of a parasite," which she "must have contracted" right after landing in São Paulo (260). Still, Uppal's ultrasensitivity about Brazil's visible and invisible menaces becomes somewhat ironic when she remarks that Toronto is being devastated by "the SARS epidemic," which is "shutting down hospital wings, placing patients and staff under quarantine, and destroying tourism" (188). Actually, there was a risk that her initial trip to Brazil might have to be aborted because of her point of departure. As her mother warns her, "You'll be tired from your flight, but try to look healthy. Don't sneeze, or you might be questioned" (29). Brazil, one imagines, is not the only perilous place in the world.

The other striking aspects of Uppal's memoir are more unusual, as they challenge widely accepted notions of the relation between race and national identity. A common explanation of why Canada has not developed more affinities with Latin America is that it "has much more in common both culturally and politically with her sister nations of the British Commonwealth, and with the democratic states of Europe, than with the South American continent" (Massey 694). More precisely, while Latin American societies are believed to fall into the "southern, 'brown' countries," Canada supposedly belongs to the "European, northern, white countries" (Kulchyski 254). Yet in Projection the Canadian Uppal is of mixed race and her Brazilian mother is white, like the rest of her family, who are of "Portuguese, Dutch, German, [and] Italian” ancestry (215). Uppal often underscores the whiteness of her Brazilian relatives in contrast to her darker complexion. In fact, one of the reasons she gives for loathing "the massive painting" that her mother hangs in her Brasília apartment of a partly naked woman and her two young children is that "the long-haired woman almost looks like melarge brown eyes, dark eyebrows, curly dark hair, high cheekbones, long nose" (182), whereas her "mother's skin is white, not brown" (183). Uppal interprets her mother's family portrait in terms of the Medea myth, saying that her mother reminds her of the legendary Greek priestess, "sacrificing her two children to hurt her husband and flee the foreign culture that drained her of her magical powers" (183). But people familiar with Brazilian national (and nationalist) iconography 
might make other connections. There is no question that the missing father is significant, underlying a motif articulated by Brazilian figures in the text, such as the taxi driver Soares, that: "The father is nothing. It is only the mother who is important" (105). However, it does not really explain why an unequivocally Caucasian Brazilian like Campos would commission a painting in which she appears to share the mixed ancestry of her children. The work of José de Alencar, in particular, might help us understand her motivation. After all, in what Uppal labels the "travesty" (184), Campos looks like Iracema, the mythical Indigenous mother of Brazil. Moreover, in her version, she survives the birth of her progeny, unlike in Alencar's narrative.

The relation between racialized bodies and national identity, though, is notable not only when it comes to the portrayal of Uppal's mother but also of Uppal. During her first flight to Brazil, her Brazilian seatmate tells Uppal, "You look Brazilian" (24). Later on, she herself remarks: "No one here thinks I'm anything but Brazilian when they set eyes upon me, until I speak. With my exotic mixed heritage, my abundant curly black hair and olive complexion, high Indian cheekbones, and my penchant for vintage clothing and party hats, I am not used to this, and find it liberating to blend in" (69). Uppal's confession that, physiognomically, she is closer to the Brazilian national image than to the Canadian one is significant because of what it reveals about North American and South American racial politics. Needless to say, neither half of the continent is racially homogeneous. Yet each region continues to possess a dominant image, which even many of its citizens accept. For example, in one of the poems she produced in Brazil in the mid-twentieth century, Elizabeth Bishop writes that her "compass/ still points north," which she associates with "blue eyes" and "flaxen-headed" youths-as well as "Protestants,/ and heavy drinkers ..." (140; ellipsis in text). A similar link between region and racial type is made in Ann Patchett's 2011 novel State of Wonder. Patchett's main protagonist is a pharmacologist named Marina Singh, who is the daughter of an Indian father and a white American mother. Although Singh was born and raised in the United States, we were told that while travelling in the Amazon, "she was able to pass in Manaus the way she was never able to pass in Minnesota" (84). In other words, Singh is North American but she purportedly looks South American. This is also the case of Uppal, which should force a reconsideration of her national politics.

Through much of Projection: Encounters with My Runaway Mother, the antagonism between Uppal and her mother reflects not just a conflict between the two of them but between Canada and Brazil. It may be true that the peoples of the Americas are all "Americanos" or "Americans," as the Argentinean-Canadian playwright Guillermo Verdecchia writes in the passage that serves as the first epigraph to this essay (20), but it would seem that many of them identify first and foremost with their specific societies. As Uppal states about half way through her memoir, she and her mother "are like warring countries that through colonization mixed long ago and no matter how separate our identity claims we are linked by history, blood, shame" (118). The two definitely spend an inordinate amount of time trying to prove to each other-and perhaps to herself-that her land is the superior one. Thus when Uppal ponders what her life and that of her brother might have been like had their mother succeeded in taking them to Brazil, she concludes: "Between Brazil and Canada, Canada would win. And I'm glad it did" (88). Although she appreciates how "beautiful and vibrant" some Brazilians are and how "sublimely glorious" are the country's "mountains and beaches," she is "aware of how many opportunities I would have lost if we'd immigrated here. We would not have been better off with my mother-able-bodied and employed and from a family of money and social standing though she is" (89). So irritated does Uppal become with the "Canada is nothing," "'Brazil is the Best"' refrain that has entered her head like "an endless soccer match" (97) that she tries to counter it by compiling a list of "Ten Things I Love About Canada" (156), which include not only the fact she "can walk outside almost any hour of the day, relatively unafraid" and "Hockey Night in Canada" (156) but also "our political system" and "my Canadian passport," which she stresses "should not need a visa to visit Brazil" (157). Campos, in turn, insists that "Canada is no better a country than Brazil. There is no democracy in Canada" (155). She also accuses her daughter of not wanting "to live in Brazil. 
You think Canada is wonderful. You and the Americans. And you come here to destroy me too. And I have cancer. If cancer will not kill me, you will kill me" (180; see also 255). Uppal concedes that the Brazil and Canada she and her mother evoke may not have much to do with the two countries bearing those names. As she writes, "Maybe Canada, to my mother, is an imaginary place, a land far, far away, where she stores all the bad and sad feelings. Canada is a villain who turned her life unfairly on its head. Who dished out a brand of justice she can't accept" (156). Still, neither woman is willing to admit publicly that the other's homeland may offer something hers does not.

Uppal is especially vocal about her patriotism. In her lecture Dreaming of Elsewhere: Observations on Home, the novelist Esi Edugyan posits, "Home is the first exile. To belong in one place is to not belong in another" (10). Edugyan, whose parents immigrated to Canada from Ghana, further asserts that "for those of us uneasy in our own skins, for those of us who have arrived in a new place, whether during our own lifetimes or by virtue of being the first generation born into a new land, a new language, a new identity, it is difficult to ignore the creeping suspicion that we are not wholly here, that some part of is not still over therewherever that 'there' might be" (10-11). Or as Caren Kaplan writes in her monograph Questions of Travel, for many people today "there is no possibility of staying at home in the conventional sense-that is, the world has changed to the point that those domestic, national, or marked spaces no longer exist" (7). But there is no such ambivalence about either national borders or national identity in Uppal, who affirms that, like her father, she is a Trudeau Canadian who passionately embraces a multicultural Canada (157). Indeed, for her, there seems to be only one holy day on the calendar, July 1 . She writes that, even as a teenager, "The only day I didn't like to work was Canada Day-a national party with strangers out on Parliament Hill, dancing to rock concerts and cheering on acrobats tossing and eating fire, open bottles of beer and wine and glow-in-the-dark necklaces and headgear; red maple leafs everywhere; I guess I felt more Canadian than part of a family" (194). If that is the case, though, if the most significant component of her personal identity is her belonging to Canada, I wonder what are the implications of her admission that she fits Brazil's national image better than that of her native land. If nothing else, it suggests that the reason travel changes people is not only that they discover new places but also that, as a consequence of those encounters, they often get to see their own societies differently.

\section{References}

Bailie, Martha. "My Mother the Film Critic." Rev. of Projection: Encounters with My Runaway Mother, by Priscila Uppal. Quill and Quire 22.1 (2014): 23. Print.

Barmak, Sarah. "Cut to the Chase: A Daughter, a Runaway Mother, a Life Lived Half in Fiction." Rev. of Projection: Encounters with My Runaway Mother, by Priscila Uppal. Globe and Mail [Toronto]. 12 Oct. 2013. R13. Print.

Bishop, Elizabeth. Edgar Allan Poe and the Juke-Box: Uncollected Poems, Drafts, and Fragments. Ed. Alice Quinn. New York: Farrar, Straus and Giroux, 2006. Print.

Braz, Albert. “The Missing Continent: Canadian Literature and Inter-American Identity." Global Realignments and the Canadian Nation in the Third Millennium. Ed. Karin Ikas. Wiesbaden: Harrassowitz, 2010. 45-54. Print.

"Outer America: Racial Hybridity and Canada's Peripheral Place in Inter-American Discourse." Canada and Its Americas: Transnational Navigations. Ed. Winfried Siemerling and Sarah Phillips Casteel. Montréal and Kingston: McGill-Queen's UP, 2010. 11933. Print.

Butor, Michel. "Travel and Writing." Trans. John Powers and K. Lisker. Mosaic 8.1 (1974): 1-16. Print.

Campos, Theresa Catharina de Góes. "A Mãe: Sua presença na vida dos filhos." 8 May 1959. Blog da Jornalista Theresa Catharina. Web. 1 Nov. 2013.

. "Messages to My Darling Son Amerjit." Undated. Web. 1 Nov. 2013.

Doshi, Tishani. "Priscila, the Poet and Social Worker." New Indian Express 12 May 2013. Web. 9 Nov. 2013.

Edugyan, Esi. Dreaming of Elsewhere: Observations on Home. Edmonton: U of Alberta $\mathrm{P}$ and Canadian Literature Centre, 2014. Print.

Kaplan, Caren. Questions of Travel: Postmodern Discourses of Displacement. Durham, NC: Duke UP, 1996. Print.

Kaplan, Jon. "6 Essential Questions." Now [Toronto]. 4 March 2014. Web. 21 March 2014. 
Kienlen, Alexis. "Memoir by Uppal a Captivating Read." Rev. of Projection: Encounters with My Runaway Mother, by Priscila Uppal. Daily Herald Tribune [Grande Prairie, AB]. 23 Jan. 2014. Web. 28 March 2014.

Kulchyski, Peter. "bush/writing: embodied deconstruction, traces of community, and writing against the state in indigenous acts of inscription." Shifting the Ground of Canadian Literary Studies. Ed. Smaro Kamboureli and Robert Zacharias. Waterloo, ON: Wilfrid Laurier UP, 2012. 249-67. Print.

Lisle, Debbie. The Global Politics of Contemporary Travel Writing. Cambridge: Cambridge UP, 2006. Print.

Massey, Vincent. "Canada and the Inter-American System.” Foreign Affairs 26.4 (1948): 693-700. Print.

Page, P.K. Brazilian Journal. Toronto: Lester and Orpen Dennys, 1987. Print.

"Fever." 1999. A Kind of Fiction. Erin, ON: Porcupine's Quill, 2001. 15-34. Print.

Patchett, Ann. State of Wonder. 2011. New York: Harper Perennial, 2012. Print.

Pratt, Mary Louise. Imperial Eyes: Travel Writing and Transculturation. London: Routledge, 1992. Print.

priscilauppal.ca. Web. 7 February 2014.

Sunshine, Fannie. "Priscila Uppal: York Resident Prepares for Debut of 6 Essential Questions." York Guardian 27 February 2014. InsideToronto.com. Web. 21 March 2014.

Uppal, Priscila. "Brazil, Under These Circumstances." Canadian Journal of Environmental Education 13.2 (2008): 79-91. Print.

Confessions of a Fertility Expert. Toronto: Exile, 1999. Print.

"Fear of Brazilians, Mothers, and Other Essential Things." Charlebois Post-Canada 9 March 2014. Web. 21 March 2014.

"In Conversation with . . . Priscila Uppal." With Ekraz Singh. Existere: Journal of Arts and Literature 33.1 (2013-14). 10-20. Print.

. "My Uncontainable Mother." Quill and Quire 79.9 (2013): 42. Print.

. Ontological Necessities. Holstein, ON: Exile, 2006. Print.

. “Poem for a Runaway Mother." Red Silk: An Anthology of South Asian Canadian Women Poets. Ed. Rishma Dunlop and Priscila Uppal. Toronto: Mansfield, 2004. 153-65.

Projection: Encounters with My Runaway Mother. Toronto: Dundurn, 2013. Print.
"Q\&A: Priscila Uppal on Writing Her First Play." Interview with Sue Carter Flinn. Quill and Quire 4 March 2014. Web. 21 March 2014.

Traumatology. Holstein, ON: Exile, 2010. Print.

Verdecchia, Guillermo. Fronteras Americanas (American Borders). 1993. Vancouver: Talonbooks, 1997. Print.

Yanofsky, Joel. “An Exercise in Family Exorcism.” Rev. of Projection: Encounters with My Runaway Mother, by Priscila Uppal. Montreal Gazette 8. Nov. 2013. Web. 14 Nov. 2013.

Recebido em: 24/04/2014 Aceito em: 05/06/2014 